\title{
THE ADVANTAGES AND CHALLENGES OF USING ICT TOOLS IN EDUCATION
}

\author{
WANG Xiaojun, CZ
}

\begin{abstract}
Review of the book: Klement, M., Dostál, J. \& Bártek, K. (2017). Perception and Possibilities of ICT Tools in the Education from the Teachers' Perspective. Olomouc: Palacký University, 170 p.
\end{abstract}

Key words: book review, information technology, education.

\section{VÝHODY A VÝZVY VYUŽITÍ ICT NÁSTROJŮ VE VZDĚLÁVÁNÍ}

\section{Resumé}

Recenze knihy: Klement, M., Dostál, J. \& Bártek, K. (2017). Perception and Possibilities of ICT Tools in the Education from the Teachers' Perspective. Olomouc: Palacký University, $170 \mathrm{~s}$.

Klíčová slova: recenze, informační technologie, vzdělávání.

The development of ICT (Information and Communication Technology) has brought great changes to education. It has changed the traditional teaching environment, learning forms, teaching content and teacher-student interactivity (Wang \& Dostál, 2016). ICT tools not only enable ubiquitous learning by ironing out time and place restrict, but also help improve the effectiveness and efficiency of the outcomes of education. With the help of ICT tools, we can combine different content forms such as audio, video, text, picture, sound, etc, into one, which produces an interactive way of learning by making the content of knowledge rich and informative, so that it can greatly enhances students' motivation and interest in learning, and makes learning from passiveness to activeness. In addition, ICT tools enable individual and independent learning to become true. In addition, it overcomes the defects of traditional learning by providing hypertexts which help extend and enrich the knowledge to be learned. Therefore, ICT tools have become a vital means to enhance the outcomes of teaching and promote quality education. Based on this, more and more researchers have paid attention to technological education and the issues related to this aspect.

The book "Perception and Possibilities of ICT Tools in the Education from the Teachers' Perspective" by Milan Klement, Jiří Dost 1, and Kvetoslav Bártek, is to provide an overview of the issues of the integration of ICT tools in basic and secondary schools and the causes of such issues in teaching practice. This book takes up crucial questions of the employment of ICT in education. The questions mainly include: the way ICT tools are employed in teaching practice? The frequency of the employment of ICT tools among teachers? Which ICT tool is the most frequently used in teaching practice? What factors influence the integration of ICT tools in education from the teachers' perspective? If there are enough hardware and software ICT tools for teaching in the subject schools? The author and co-author offer readers the answers to these questions by conducting two empirical studies. The first one is concerned with the current state of the integration of ICT tools in education in a broad sense and the second one deals with the current state of the employment of ICT tools in realizing problem-based teaching in basic and secondary schools. The studies were conducted at 35 schools in Czech Republic, including pre-primary schools, basic schools and secondary schools.

The book includes five chapters. The first chapter is about the contemporary possibilities of using ICT tools in education. This chapter mainly discusses two functions of ICT tools in education: ICT 
tools as a teaching aid and ICT tools as a teaching means and compares the differences between these two concepts. The former in a school practice is mainly concerned about teaching about ICT tools. In this circumstance, an ICT tool becomes an object of teaching. That means to teach pupils about how to use hardware and software application. The authors pointed out that it is necessary to impart needed skills about ICT tools to students. The latter---ICT tools as a teaching means--- regards ICT tools as technical teaching means which commonly harness audiovisual technology to achieve effective teaching outcomes. In this chapter, a TPCK model of teachers' competences necessary to employ ICT tools in the education is also discussed. The following chapter (chapter2) elaborates the difficulties, challenges and trends in the integration of ICT tools in education. In this chapter, the authors also compare two concepts--- the traditional and contemporary concept of multimedia. According to the authors, the traditional concept of multimedia perceives multimedia as a way of using more means to present courses and to build up communication with students while the contemporary concept of multimedia views multimedia“" as an interconnection of various functions which can provide media (text, video, graphics, animations, simulations, etc.). The computer functions here as a combiner of these functions which results in a multichannel mediation of information"(B.Brdicka,2003). In other words, multimedia combines various content forms such as text, tables, graphs, animations, images, sound, video, animation, etc, to facilitate learning (Dostál, 2009). The third chapter is about the current state of the integration of ICT tools in pre-primary, basic, secondary schools in Czech Republic. This chapter addresses the ways and the frequency of the employment of ICT tools in education, the preferences of ICT tools teachers use for different teaching tasks, including preparing teaching materials, realizing frontal teaching and individualized teaching, the availability of hardware and software ICT tools for teachers, the way of acquisition of software ICT tools, the sufficiency and availability of electronic learning materials, the sufficiency of the amount and quality of ICT tools available, teachers' interest in the acquisition of additional ICT tools, demanded support necessary for more employment of ICT tools in the teaching, the frequency of using ICT tools in the following teaching practice: summarizing the subject matter taught, making teaching more varied, classification setting, test evaluation, tests preparation, teaching itself and preparation for teaching. The research adopts quantitative methodology by using questionnaire to obtain data. The structure and the content of questionnaire are displayed in this chapter, which constitutes a good paradigm and reference for future researchers interested in this research field. Besides, the findings provide valuable information for educators and education policy-makers who care for the integration of ICT tools in education in Czech Republic as well as in other countries. The fourth chapter describes theoretically the issues of development of the ability to solve problems among basic and secondary school pupils with support of ICT tools. In this chapter, the author emphasized that the teacher is a decisive factor influencing the form of teaching and the choice of strategies to develop the ability to solve problem. They also influence whether and how modern ICT tools will be included in this process (Klement et al, 2017). The last chapter focuses on the current state of the employment of ICT in problem-based teaching as problem-solving ability is very important to students and has become an educational goal stated in educational program in Czech Republic. This research was also conducted in 35 schools, including pre-primary schools, basic schools and secondary schools. Specifically, it deals with whether teachers (basic school teachers and secondary school teachers) use ICT tools to develop the ability to solve problems, teachers' motive for employment and non-employment of ICT tools to develop pupils' ability to solve problems, whether there are differences in the employment of ICT tools to develop the ability to solve problems between the teachers of certain subjects and teachers of other qualification, whether there are differences in the frequencies of the employment of ICT to develop the ability to solve problems between male teachers and female teachers. 
In summary, this book meets the exceptions of the readers who open it. It dwells with current situation of the integration of ICT tools in pre-primary, basic, and secondary schools. It combines theory and practice. Although the subject schools in the research are in Czech Republic, this book is a valuable reference for researchers and educators who are concerned with the integration of ICT tools in other countries all over the world as there, to some extent, exists shared problem in education fields. Even though this book mainly discusses the use of ICT tools in pre-primary, basic and secondary schools, it is still helpful for those who concern about the same issues in higher stages of education.

\section{References}

Brdička, B. (2003). Role Internetu ve vzděláváni: studijní materiál pro učitele snažicí se uplatnit moderní technologie ve výuce. Kladno: AISIS, 122 p.

Dostál, J. (2009). Multimedia, hypertext and hypermedia teaching aids - current trend in education. In. Journal of Technology and Information Education, 3(1). Olomouc-EU, UP Publishing, pp. 45-56. Klement, M, Dostál, J. \& Bártek, K. (2017). Perception and Possibilities of ICT Tools in the Education from the Teachers' Perspective. Olomouc: Palacký University, 170 p.

Wang, X., Dostál, J. (2016). Analysis of Options Promoting Education of English Through ICT. 2016 4th International Conference on Advances in Social Science, Humanities, and Management (ASSHM 2016). pp. 111- 115. DOI 10.12783/dtssehs/asshm2016/8343.

\section{Kontaktní adresa:}

\section{Xiaojun Wang}

Katedra technické a informační výchovy, Pedagogická fakulta UP, Žižkovo nám. 5, 77140

Olomouc, ČR, tel.: 00420585635 820, fax +420 585231 400, e-mail: xiaojun.wang02@upol.cz 